\title{
The Application of Group Training-Based Guidance Strategies to Develop the Gratitude of Aceh Adolescents in Maintaining Peace
}

\author{
Martunis* \\ Bimbingan dan Konseling \\ FKIP Universitas Syiah Kuala \\ Banda Aceh, Indonesia \\ martunis_yahya@unsyiah.ac.id*
}

\author{
Abu Bakar \\ Bimbingan dan Konseling \\ FKIP Universitas Syiah Kuala \\ Banda Aceh, Indonesia \\ abubakar196712@gmail.com
}

\author{
Fitra Marsela \\ Bimbingan dan Konseling \\ FKIP Universitas Syiah Kuala \\ Banda Aceh, Indonesia \\ fitramarsela.fm@gmail.com
}

\begin{abstract}
After long conflict in Aceh, both large and small scale conflict such as brawls between vocational students with senior high school students, more or less needs to be a concern for maintenance so as not to recur. The teaching and learning process at school will run well if the physical and psychological environment is condusive. Conversely, conflict and violence in the school environment can have a negative impact on the continuity of the teaching and learning process. Peace is an absolute solution to eliminate the remaining conflicts both in the community and in the school and family environment. The existence of peace must be thankful for and safeguarded so as not to again cause a prolonged conflict. This study aims to determine the application of the effectiveness of group trainingbased guidance strategies for the development of gratitude of Aceh adolescents in maintening peace. The approach taken in this research is quatitative with a quasi- experimental research method. The research locations are schools in the Aceh conflict area and schools that have experienced conflict/brawl between students in Aceh the last five years published by the media, namely SMKN 1 Bireun and SMAN 2 Bireun, and SMKN 2 Langsa and SMAN 1 Langsa. The populations in this study were teenagers in grade XI SMA and SMK. The sample was taken with a purposive sampling technique. Data collection was carried out with a questionnaire instrument in the form of a likert scale that was able to describe the characteristics of adolescents having gratitude in maintaining peace. The result showed that there were differences in the pretest and post test scores of the experimental class with the exact sig scores ( 1 tailed) of $0,028<0,05$. This shows the post-gratitude score of adolescent gratitude has a good influence with an average increase in the experimental group in the post test (125.16) greater than the pretest $(\mathbf{1 0 5 . 8 4})$. It means that group trainingbased guidance strategies are effective in developing the gratitude of Acehnese adolescents in maintening peace.
\end{abstract}

Keywords—guidance, group training, gratitude, peace

\section{INTRODUCTION}

School as a social system is a means in the process of student learning as the successor to the nation. Through education in school, the nation's next generation must be able to improve cognitive, affective and psychomotor abilities. This is confirmed in Law No 20 of 2003 concerning the purpose of education which is oriented towards the personal development of the aspired Indonesian human namely [1] Having faith and devotion to an Almighty God; [2] having good morals; [3] have knowledge and skills; [4] has physical and spiritual health; [5] has a strong and independent personality; [6] has a sense of social and national responsibility. The achievement of the educational goals related to physical and spiritual health needs to be prioritized. Physical health is physical health, while spiritual health is psychological health which is able to generate motivation to behave productively. But in reality, today's teens are less aware of emotions and tend to be unstable in managing emotions.

Talking about the basic factors that influence the success of education such as physical and spiritual factors, one important factor is the environment. Like other factors, the environment that includes adolescent socializing areas includes the family, school and community. Schools play a very important role for adolescents as formal institutions that are social in nature. It should be conducive to support the learning process. The learning process will run well if the physical and psychological environment is conducive, conversely conflict and violence in the school environment can have a negative impact on teaching and learning can hinder students' success in studies.

Conflicts that occur in large-scale communities and conflicts that occur between adolescents in small-scale school environments are able to influence the learning process. The following is a description of cases related to conflicts / brawls between students which also often occur which lead to fellow student victims or damage to public facilities such as school buildings / facilities. The same incident also occurred conflict / brawl between students of SMK 1 Bireun and SMAN 2 Bireun on March 4, 2015 only because of minor problems and inheritance sentiment. The brawl caused a CCTV belonging to the school to be destroyed and several school windows were broken because they were stoned. Besides that a teacher was injured due to student tantrums[1]. Similar events have also occurred between SMK 2 Langsa and SMAN 1 Langsa, starting with mutual taunts between the two camps and ending with the attack on SMAN 1 by SMKN 2[2]. Due to the incident a number of SMAN 1 facilities were damaged such as the outbreak the glass of dozens of study rooms, halls, student rooms, and musala of the favorite high school, and injured three students who must be treated at Langsa Regional Hospital. 
Based on the description of cases of conflict that occurred to Aceh adolescents in recent years illustrated that conflict between adolescents cannot be allowed to continue because it can harm adolescents and hamper success in their education. The conflict between high school students in Bireun City and Langsa City has also received attention from counseling guidance teachers, school principals, teachers and other stalkholders. This is evident from the implementation of mediation counseling strategies in conflict resolution between students of SMK 1 Bireun and SMAN 2 Bireun, and mediation counseling between SMK 2 Langsa and SMA I Langsa. The mediation effort is said to be successful because it has resulted in harmonious relations / brotherhood between students who have been involved in conflict, as well as good relations between the two schools such as mutual cooperation together in the school environment, involving each other as ceremonial officials in turn and inviting each other to attend the event on Islamic Holidays [3].

Other research that carries efforts to prevent conflict through counseling guidance strategies is also illustrated in the research[4] that uses conflict resolution counseling strategies to overcome interpersonal conflict in high school students. The results showed that conflict resolution counseling was effective in increasing the average score of perception of conflict by 101.92 or by $37.47 \%$ based on the maximum score percentage. This achievement is higher than usual counseling which only reached 13.08 or with an increase of $4.8 \%$ to the maximum score. These studies indicate that conflict resolution in high school adolescents can be done by providing guidance and counseling strategies.

Guidance and counseling strategies efforts are able to be a curative effort to resolve internal conflicts between the two schools, but in maintaining peace and avoiding long-term conflict there needs to be suistanable efforts from various parties so that preventive efforts are needed to maintain peace between teenagers in the two schools. Various approaches can be carried out by the guidance and counseling teacher with stakeholders including a group training-based guidance strategy for the development of gratitude of adolescents in maintaining peace in order to avoid prolonged conflict. Guidance and counseling strategies based on group exercises are given to develop gratitude for the peace that adolescents have gained. A group training-based guidance strategy consists of a series of exercises for groups of teenagers which are able to develop gratitude to maintain and interpret the peace that has been obtained.

\section{METHOD}

This research uses a quantitative approach with a quasi-experimental method using one group pre-test-post test design. The population of this research is the XI grade students of SMK 1 Bireuen, SMAN 2 Bireun, SMK 2 Langsa and SMAN 1 Langsa. The sample of this study was 115 grade XI students of SMK and High School totaling 115 teenagers in Bireun City and Langsa, Aceh. Data collection of gratitude is obtained from the gratitude instruments of teenagers in maintaining peace.

\section{RESULT AND DISCUSSION}

Result

1. General Description of Adolescents' Gratitude

The results showed that the level of gratitude of adolescents in maintaining peace was in the moderate category. This can be seen from the number of frequency of answers of adolescents, mostly 73 adolescents or as much as $63 \%$ are in the medium category. Thus, it can be concluded that the level of gratitude of Acehnese adolescents in maintaining peace in high school is in the medium category, and is presented in the following:

Table 1. Table Description of Adolescent Feelings in Vocational School (SMK) and High School (SMA) of Bireuen and Langsa Cities In Pre-Test and Postest

\begin{tabular}{|c|c|c|c|c|}
\hline & Category & IntervalScore & Frequency & Percentage \\
\hline 1 & High & $>89$ & 17 & $15 \%$ \\
\hline 2 & Medium & $89-76$ & 73 & $63 \%$ \\
\hline 3 & Low & $<76$ & 25 & $22 \%$ \\
\hline \multicolumn{2}{|c|}{ Amount } & 115 & $100 \%$ \\
\hline
\end{tabular}

2. Effectiveness of Guidance-Based Group Training for the Development of Gratitude for Acehnese Youth in Safeguarding Peace.

Descriptions of the effectiveness of group trainingbased guidance strategies for the development of gratitude of adolescents in maintaining peace can be described through comparison of the pretest and posttest scores of the experimental class. Through statistical tests, it was found that the sample is not normally distributed. Based on the ShapiroWilk normality test, it can be concluded that the sample did not normally distribute, so the homogeneity test was not carried out and directly tested for differences in the pretest and posttest scores and the similarity of the two averages using the non-parametric Mann-Whitney statistical test. Results Statistical tests were carried out to determine the effectiveness of group training-based guidance strategies for developing Aceh's gratitude in maintaining peace. The results of testing the effectiveness of group-based guidance for developing teenage gratitude in maintaining peace use the Mann-Whitney U Test.

\section{Difference between Pretest and Postest Score in the Experiment Group}

The difference in the pretest and posttest scores in the experimental group uses non-parametric test statistics, namely the Mann-Whitney test. Output from Mann-Whitney test analysis is presented in the following table:

Table 2. Table of Test Results of Pretest and Posttest Score Differences in The Gratitude of Adolescents of Experiment Class

\begin{tabular}{|l|c|c|c|c|}
\hline & Pretest dan Postest & $\begin{array}{c}\text { Exact. Sig } \\
(1 \text {-tailed })\end{array}$ & $\alpha$ & Description \\
\hline 1. & Eksperiment Class & 0.028 & 0.05 & Significant \\
\hline Note: \\
Score Sig $(1$-tailed $)<\alpha(0,05)=$ significant \\
Score Sig $(1$-tailed $)>\alpha(0,05)=$ not significant \\
\hline
\end{tabular}


Based on the "Test Statistics" output it is known that the Exact Sig. (1 tailed) of $0.028<0.05$. This shows that the posttest score of adolescent gratitude is higher than the pretest score of the experiment class. So it can be concluded that the post-test score of adolescent gratitude has a good influence power.

\section{Difference in mean of pre-test and posttest of Experiment group}

Table 3. The Result of Differences in The Mean Rank Test of Adolescent Gratitude Test of SMK and SMA in Bireun and Langsa in The Pre-Test and Postest

\begin{tabular}{|c|c|c|}
\hline & $\begin{array}{l}\text { Mean Rank } \\
\text { Eksperimen }\end{array}$ & Sum of Ranks \\
\hline Pretest & 105.84 & 12172.00 \\
\hline Postest & 125.16 & 14393.00 \\
\hline
\end{tabular}

Based on the results table of Man-Whitney U Test, shows that the average increase in the experimental class in the post-test (125.16) is greater than the pre-test (105.84). The difference between the pretest and posttest of the experimental group can be seen from the following graph:

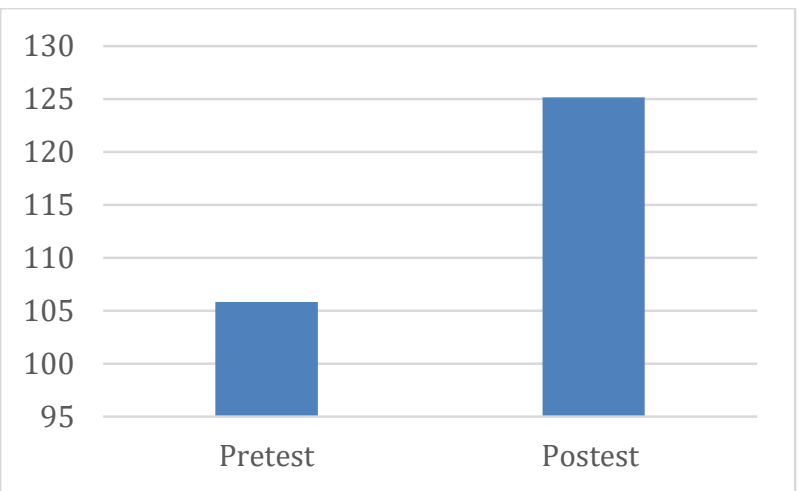

Fig. 1. Difference of pretest and posttest average of experiment group

\section{Discussion}

Characteristics of gratitude of Acehnese adolescents in maintaining peace are mostly in the medium category, meaning that they feel insufficient with the achievement of peace they have, are less consistent in realizing that peace is felt to have been fair and has many gifts, not consistent in looking positively at daily routines, easy to complain and bored with daily activities in maintaining peace, less aware that peace today is a gift from God, less aware of the goodness of others, tend to forget the goodness of others and rarely express the goodness of others that are useful for the creation of peace. The results of this study were strengthened by the students' journals on the research side, including: Less in part (49.57\%) they revealed; try to maintain peace by preventing / overcoming friends who fight / / conflict /brawl, then less in part $(48.70 \%)$ they are also not easy to accept and do not want to spread the news / information that is not clear (hoax), always maintain relationships both between friends at school and other schools. Some less $(37.39 \%)$ they have patience and courage in dealing with problems, and are able to control emotions, then less in part also (33.91\%) they often participate in mutual cooperation both conducted in their own schools, and carried out in other schools. The students' journal results were also revealed that "achievements in life are achievements made in maintaining peace"; a small number said they had never been summoned to the guidance and counseling room (BK room) for disciplinary violations committed / having problems.

The characteristics of gratitude in the medium category experienced by adolescents certainly need to be developed so that adolescents achieve a positive quality of life in maintaining peace. Characteristics of adolescent gratitude that are in the low category in maintaining peace, this is like; Feeling dissatisfied with self-achievement in maintaining peace, often complaining that peace is currently far from perfection, having problems with quality of life and achievement, having no concern in interpreting simple things in daily activities, slightly appreciating the gift of peace given God such as a sense of security and calm and too ignores the kindness of others who have contributed to creating peace. The results of youth journals in the low category can be conveyed, among others: almost in part $(28.70 \%)$ they have lack patience and are less able to control emotions, lack discipline, have been involved in student brawls with other schools, or fight with friends in their school and with other school students, even some of them $(10.43 \%)$ have received punishment from school for not being disciplined, such as ditching, fighting, smoking, sleeping in class while the teacher teaches, or not making homework given by teachers.

Gratitude will cause someone to benefit emotionally and interpersonally. By seeing and feeling suffering as something positive, a person will be able to increase his new coping ability both consciously and unconsciously, can trigger the emergence of self-meaning that will bring one's life into a more positive direction [5].

Furthermore, several studies also show that gratitude can prevent depressive and pathological conditions[5]. A person who is grateful has a higher control over his environment, personal growth, has a goal life, and selfacceptance: People who are grateful also have positive coping in dealing with life's difficulties, seek social support from others, interpret experiences with different perspectives, have plans to solve problems [6]. Gratitude can also help someone to be able to improve their ability to deal with problems and find the best solution for the problem. The gratitude possessed by someone can indicate how far he feels happy (well-being) seen from satisfaction with his life (satisfaction with life) [7].

The component of gratitude is in accordance with the opinion of [8], namely people who are grateful to have a good will to someone or something, a tendency to act based on appreciation and good will they have, and realize the importance of expressing gratitude. Gratitude is not only related to appreciation of what is obtained, but there is also an element of expression of appreciation and feelings that can be realized in action [6].

Gratitude is one of the positive emotions found in an individual $[9,10]$. According to [11] gratitude as a positive emotion, gratitude is a unique feeling that arises when individuals receive kindness, compassion, love, benefit or get help from others. Based on the above opinion it can be 
concluded that gratitude is all the feelings of gratitude for the achievement of individual lives in the present by not forgetting valuable experiences in the past. The feeling of gratitude is also inseparable from the influence of parties outside the individual who have helped in the achievement of his life such as God, the universe, and people around the individual.

The increase in the posttest score of gratitude of vocational and high school adolescents in Bireuen City and Langsa in the experimental class was influenced by many factors, both from an internal perspective (understanding of the material, readiness to participate in group exercises and the desire to change) as well as from an external aspect (methods, facilitators and support from surrounding environment). The development of gratitude of teenagers by vocational and high school teenagers in Bireuen and Langsa City is not only seen from the change in scores statistically, but also based on changes in behavior during the intervention session. In this study the actively journal and feedback sheet filled out after the service session are very helpful in assessing the changes that occur in vocational and high school teenagers in Bireuen and Langsa.

Group training-based guidance strategies are effective to develop gratitude for vocational and high school adolescents in Bireuen City and Langsa in maintaining peace. This is evidenced by an increase in the average post-test score of the experimental group. Besides being proven by comparing the average score, qualitative observations were also carried out which marked a process of change in vocational and high school adolescents in Bireuen and Langsa. These changes were analyzed based on observations and activity journals so that it can be seen that the guidance structure based on group exercises is effective in developing gratitude of vocational and high school adolescents in Bireuen and Langsa in maintaining peace reflected from the improvement of aspects of gratitude in the experimental group.

\section{IV.CONCLUSION}

In general, the gratitude of teenagers in class XI of SMKN and SMAN in Bireuen and Langsa in maintaining peace is in the moderate category. Characteristics of gratitude of adolescents who are in the medium category such as marked by not feeling enough with the achievements or achievements, less consistent in realizing that life is fair and have many gifts, less consistent in seeing positive daily routines, easy to complain and bored with daily activities, less aware of the beauty of the natural surroundings, often ignore the kindness of others, tend to forget the goodness of others and rarely express the goodness of others that benefit themselves. The characteristics of gratitude are needed to be developed so that adolescents achieve a positive quality of life.
The Effectiveness of Guidance Based on Group Exercise for Developing Youth Gratitude in Maintaining Peace is described in the first few assumptions, comparing the pretest and posttest scores of the experimental class using nonparametric test statistics, namely with the Mann-Whitney test, the results of the first assumption are known that the Exact Sig. ( 1 tailed) of $0.028<0.05$. These results state that the change in the pretest to posttest scores is very significant, so it can be concluded that the posttest scores of adolescent gratitude are higher than the pretest scores of the experimental class. So it can be said that the post-test scores of adolescent gratitude have a good influence. The second assumption by comparing the average increase in the experimental group at the post-test (125.16) is greater than the pre-test (105.84). Based on these two assumptions, it can be concluded that the guidance strategy based on group training is effective in developing the gratitude of Acehnese adolescents in maintaining peace.

\section{ACKNOWLEDGMENT}

Thanks to all stakeholders of SMKN 1 Bireen, SMAN 2 Bireun, SMKN 2 Langsa and SMAN 1 Langsa. The research team also say thanks and appreciation to the research sponsoring institution, LPPM Syiah Kuala University in funding this research.

\section{REFERENCES}

[1] www. google. Kompas.com, 4 Maret 2015, Siswa Dua SMTA di Bireun Aceh Tawuran, CCTV Hancur dan Satu Guru Terluka, Diakses 1 November 2018.

[2] www.google. Serambi Indonesia. com, Tawuran, Siswa SMA N 4 Dievakuasi, Diakses tanggal 1 November 2018.

[3] Martunis, dkk. "Strategy of Meditiation Counseling for The Resolution of Conflict Among Students Based On Acehnese Local Wisdom" Prosiding Seminar Nasional Konvensi BK ke XX, 2018.

[4] Purwoko, B., Prawitasari, J. E., Atmoko, A., \& Handarini, D. M. Keefektifan Konseling Resolusi Konflik untuk Mengatasi Konflik Interpersonal pada Siswa Sekolah Menengah Atas, 4(1), 53-63. 2016

[5] Emmons, R.A., \& McCullought, M.E. The Psychology of Gratitude. Oxford University. 2004.

[6] Seligman, M.E.P \& Csikzentmihalyi, M. Positive Pshychology; an introduction. An America Psychological Association. Inc. 55, no. 5-14. 2000.

[7] Watkins, P. C., Woodward, K., Stone, T., \& Kolts, R. L. Gratitude and Happiness: Development of a Measure of Gratitude, and Relationships With Subjective Well-Being. Social Behavior and Personality: An International Journal, 31(5), 431-451.2003.

[8] Fitzgerald, P. Gratitude and justice. Ethics, 109, 119-153. 1998.

[9] Krause, N. Gratitude Toward God, Stress, and Health in Late Life. Research on Aging, 28(2), 163-183. 2006.

[10]Li, S. How to Make a Grateful Child? Reflection on Gratitude Campaigns in China in Recent Years. SAGE Open, 4(4). 2014.

[11] Arif, S. Iman. Psikologi Positif. Jakarta: Gramedia, 2016. 